\title{
REALISING THE AFRICA MINING VISION: THE ROLE OF GOVERNMENT-INITIATED INTERNATIONAL DEVELOPMENT THINK-TANKS
}

\author{
Chilenye Nwapi*
}

\section{INTRODUCTION}

In 2008, the United Nations Economic Commission for Africa (UNECA) and the African Union (AU) established a joint technical taskforce to articulate a mining vision for Africa. The resulting Africa Mining Vision (AMV), which was adopted by African Heads of State and Government in February 2009, was informed by the continent's recognition of its enormous mineral potential, the importance of mineral resources to Africa's industrialisation and socioeconomic development, and the fact that in most African countries only very little progress has been made to maximise the opportunities. ${ }^{1}$ The AMV represents a "common voice" for Africa in the "negotiat[ion] of access to the continent's natural resource wealth". ${ }^{2}$ Its central theory is that Africa's mineral resources can play a transformative role in Africa's development only if appropriate socio-economic development linkages that meet national and regional developmental needs are established. It calls for a " $[\mathrm{t}]$ ransparent, equitable and optimal exploitation of mineral resources to underpin broad-

doi: http://dx.doi.org/10.4314/jsdlp.v6i2.8

* Senior Fellow, Institute for Oil, Gas, Energy, Environment and Sustainable Development Afe Babalola University, Nigeria. This article is a revised version of a paper presented at the Southern African Institute of Mining and Metallurgy's "Mining, Environment and Society" Conference: Beyond Sustainability - Building Resilience, held in Johannesburg from 12-13 May 2015. The Institute reserved the right to publish that earlier version in its journal.

1 African Union (AU), Africa Mining Vision, February 2009, < http://pages.au.int/ sites/default/files/Africa\%20Mining\%20Vision\%20english_0.pdf $>$ accessed 8 December 2015.

2 H Besada \& P Martin, "Mining Codes in Africa: Emergence of a 'Fourth' Generation", North South Institute Research Paper, March 2013, 17, <www.nsiins.ca/wp-content/uploads/2013/03/Mining-Codes-in-Africa-ReportHany.pdf $>$ accessed 8 December 2015. 
based sustainable growth and socio-economic development". ${ }^{3}$ The critical question is: how can this vision be realised?

This article focuses on the role of government-initiated international development think tanks in the realisation of the AMV. Although there is lack of agreement about the meaning of think-tanks, the following definition by the United Nations Development Programme is widely cited: think-tanks are "organisations engaged on a regular basis in research and advocacy on any matter related to public policy. They are the bridge between knowledge and power in modern democracies." 4 Government-initiated international development think-tanks refer to those think-tanks working in the field of international development that do not merely receive government support, but that were established by governments in partnership with the private sector with the overarching goal of furthering the governments' economic diplomacy and overall foreign policy objectives. Two examples of such thinktanks are Australia's International Mining for Development Centre (IM4DC) and the Canadian International Resources and Development Institute (CIRDI) (formerly Canadian International Institute for Extractive Industries and Development). IM4DC was established through an initiative of the Australian Aid for International Development (AusAID) as part of the Australian government's Mining for Development Initiative which seeks to provide support to developing countries to manage their extractive industries for economic growth and poverty reduction. Its priorities include supporting the "Australian government's economic diplomacy agenda." ${ }^{5}$

Similarly, CIRDI was established with funding from the now defunct Canadian International Development Agency (CIDA) for the exact goal that IM4DC was established. This goal aligns with Canada's new foreign aid policy, which seeks to establish partnerships with the private sector in developing countries in a bid to improve the development impact of the activities of Canadian corporations in those countries. IM4DC and CIRDI are thus direct implementations of their respective countries' foreign aid policies. These countries' huge investments in African mining allude to the priority focus areas of their two think-tanks.

3 AU (n 1) v.

4 United Nations Development Programme (UNDP), Thinking the Unthinkable: From Thought to Policy - The Role of Think Tanks in Shaping Government Strategy: Experiences from Central and Eastern Europe (Bratislava: UNDP Regional Bureau for Europe and the Commonwealth of Independent States, 2003) 6.

5 IM4DC, Mid-Term Review of International Mining for Development Centre (IM4DC): Final Report (April 2014) 9 < http://aid.dfat.gov.au/aidissues/mining/ Documents/im4dc-mid-term-review-april14.pdf > accessed 9 December 2015. 
This article critically reviews the programmes and strategies of IM4DC and CIRDI with a view to analysing how they could contribute to the realisation of the AMV. Notably, both think-tanks are relatively new - IM4DC was established in 2011 and CIRDI in 2013. This makes it premature to assess their impact on their partner countries at this time. Nonetheless, it remains worthwhile to take a close look at their programmes, strategies and outcomes to evaluate their potential to contribute to the realisation of the AMV. In what ways can they be made more effective for the realisation of the AMV? The paper then proceeds to discuss how African countries can take optimal advantage of the opportunities created by the establishment of these thinktanks in order to realise the goals of the AMV.

Section 2 of this article reviews the main components of the AMV as well as its significance to Africa's economic development strategy. Sections 3 and 4 review the programmes and strategies of IM4DC and CIRDI. The review of programmes and strategies of the two think-tanks is extended in Section 5 with a view to identifying their strengths and weaknesses. This is then followed in Section 6 by a discussion of how African countries can leverage the opportunities presented by the programmes of these think-tanks to enhance the realisation of the AMV. So far, the activities of the think-tanks have focused primarily on capacity building. This section, therefore, focuses on how African countries can harness the capacity building opportunities created by the thinktanks. The discussion is centred on the use of local content requirements in the mining sector. A broader discussion of how Africa can harness the potentials of its mineral resources is beyond the scope of this paper. Section 7 concludes the discussion.

\section{THE AMV}

The AMV posits that achieving its goals requires strategies and interventions coordinated at the continental level and implemented at the national and sub-regional levels. ${ }^{6}$ It emphasises the need for "more fiscal space and responsive taxation to allow host countries to better capture windfall gains and to encourage the use of revenues for value addition and linkages." " It

6 AU (n 1) 30.

7 MA Pedro "The Africa Mining Vision: Towards Shared Benefits and Economic Transformation", GREAT Insights, Volume 1, Issue 5, July 2012, <http:// ecdpm.org/great-insights/extractive-sector-for-development/the-africa-miningvision-towards-shared-benefits-and-economic-transformation/ $>9$ December 2015. 
also emphasises other gains that can be derived from mining, through "employment generation, local procurement of goods and services, entrepreneurial development, skills and knowledge creation, technology transfer, infrastructure expansion and above all linkages". ${ }^{8}$ It identifies "critical constraints and success factors' for its realisation, namely, the quality of resource potential data, capacity to negotiate contracts, resource development and governance capacity, capacity to manage mineral wealth, infrastructural constraints, and the challenges associated with artisanal and small-scale mining. ${ }^{9}$ It further establishes a tentative framework for action to be fleshed out and implemented at the regional and national levels.

The adoption of the vision has been described as a landmark in mining sector governance in Africa and represents "a paradigm shift" from the neoliberal framework that has governed mineral development in Africa for decades. ${ }^{10}$ Its adoption has been traced to an upswing in mineral prices in the years before the global financial crisis of 2008 and the "yawning gap" between the profits of the mining corporations and the revenues that accrued to African governments. ${ }^{11}$ The vision is, therefore, a broad philosophical articulation of the steps that African countries need to take in order to retain a greater share of the revenues accruing from the development of its mineral resources.

In 2011, the AU and UNECA issued a report titled Minerals and Africa's Development: The International Study Group Report on Africa's Mineral Regimes, intended to serve as a reference to policy makers for the implementation of the vision. ${ }^{12}$ This report formed the basis for an Action Plan agreed to in December 2011 during the Second AU Conference of Ministers Responsible for Mineral Development. ${ }^{13}$ At the Eighth African Development

8 ibid.

9 AU (n 1) 14.

10 The Third World Network Africa, "Conceptual Framework: 'Africa Mining Vision and ECOWAS Mineral Development Policy", Accra, Ghana, 3-7 November 2014, p 2, <http://www.daghammarskjold.se/wp-content/uploads/2014/12/ Conceptual-Framework5.pdf $>9$ December 2015.

11 Ibid.

12 UNECA \& AU, Minerals and Africa's Development: The International Study Group Report on Africa's Mineral Regimes, November 2011, < http://www.africamining vision.org/amv_resources/AMV/ISG\%20Report_eng.pdf>9 December 2015.

13 AU, African Development Bank \& UNECA, Building a sustainable future for Africa's extractive industry: From vision to action - Action Plan for Implementing the AMV, December 2011, <http://pages.au.int/sites/default/files/Action\%20Plan\%20 Final\%20Version\%20Jan\%202012\%20\%282\%29.pdf> 9 December 2015. 
Forum in 2012, UNECA, supported by mining firm AngloGold Ashanti, launched the African Mineral Skills Initiative (AMSI) as a vehicle for the implementation of the AMV ${ }^{14}$ The goal of AMSI is to reduce the skills shortage in the mining sector in Africa. In December 2013, the African Minerals Development Centre (AMDC) was established to coordinate all activities relating to the AMV's implementation. Regional economic communities as well as individual countries are expected to design mechanisms for the implementation of the AMV within their jurisdictions.

\section{UNDERSTANDING THINK-TANKS}

The exact origin of think-tanks is not known. It is believed that the idea may have originated from an Englishman named Thomas Clarkson, who in 1782 founded the Society for the Abolition of the African Slave Trade. ${ }^{15}$ Observably, it was in the 20th century that think-tanks became prominent, foremost among them being the RAND Corporation and the Brookings Institution established in the United States. It has been said that most of the public policy great ideas that drive the Western societies today, such as the ideas of Medicare and Medicaid in the United States, originated from think-tanks. ${ }^{16}$

As earlier noted, there is a lack of agreement about the meaning of think-tanks. McGann and Weaver's definition of think-tanks as "nongovernmental, not-for-profit research organisations with substantial organisational autonomy from government and from societal interests such as firms, interest groups, and political parties"17 is widely referenced, despite its shortcomings. Goodman has suggested that "[a] think tank is an organisation that sponsors research on specific problems, encourages the discovery of solutions, and facilitates interaction among scientists and

14 Economic Commission for Africa, "Africa Mineral Skills Initiative - Concept Note: Building Human Capacity and Strengthening Institutions in the Extractive Industries in Africa", Pre-ADV VIII Event, 22 October 2012, <http:// www1.uneca.org/Portals/adfviii/Documents/Pre-ADF/PreADFVIIIConcept NoteAfricanMineralsSkills Initiative.pdf $>11$ December 2015.

15 John C Goodman, "What is a Think Tank?" (2005) National Centre for Policy Analysis, $3<$ www.atlasnetwork.org/assets/uploads/misc/chapter-3-what-isathink-tank-goodman.pdf $>$ accessed 11 December 2015.

16 ibid 4.

17 JG McGann \& RK Weaver, Think Tanks and Civil Societies (Transaction Publishers, 2005) 5 . 
intellectuals in pursuit of these goals." ${ }^{18}$ Pautz has opined that "[ $\left.t\right]$ he criterion for a think-tank being a 'non-governmental' organisation is generally accepted in the literature as long as this does not exclude organisations that receive project and basic funding from governmental sources." 19 Pautz also questions the "not-for-profit" criterion in the definition as irrelevant because, among other things, it masks the fact that think-tanks always seek to gain something, even if that thing is not financial gain. ${ }^{20}$ Pautz suggested the following detailed definition:

Think-tanks are non-governmental institutions; intellectually, organisationally and financially autonomous from government, political parties or organised interests; and set up with the aim of influencing policy. They have no formal decision-making power and claim political neutrality while often making no secret of their ideological standpoints. Some carry out little research themselves and commission external experts or recycle existing research, while others have considerable internal research capacities. Furthermore, think-tanks want to change policy through intellectual argument rather than through behind-the-scenes lobbying. They employ rhetoric of public spirit and of the "common good". They advocate ideas, develop and maintain policy networks, and provide expertise to policymakers. They inform decision makers about policy developments from other countries and can thus facilitate policy learning. ${ }^{21}$

Apparent in the definitions is that think-tanks are varied and they can be private sector-initiated or government-initiated. Funding source would appear to be irrelevant to the understanding of which organisation qualifies as a think-tank. University institutes, management consultancies within the policy advice arena, ${ }^{22}$ policy research institutions such as the British Institute of International Affairs and government contract research institutions, such as the RAND Corporation and the Canadian Institute for International Peace and

18 John C Goodman (n 15) 1 <www. atlasnetwork.org/assets/uploads/misc/ chapter-3-what-is-athink-tank-goodman.pdf $>$ accessed 11 December 2015.

19 Hartwig Pautz, "Revisiting the Think-tank Phenomenon" (2011) 26(4) Public Policy \& Administration 421.

20 ibid.

21 ibid 423.

22 ibid 422. 
Security ${ }^{23}$ are regarded as think-tanks. So are advocacy groups such as the Heritage Foundation and the Institute for Policy Studies ${ }^{24}$ and international development agencies/institutes such as the United States' Centre for Global Development and Canada's International Development Research Centre. Both IM4DC and CIRDI would also qualify as international development thinktanks.

\section{AN OVERVIEW OF IM4DC AND CIRDI AND THEIR PROGRAMIMES}

\subsection{IM4DC}

IM4DC was established by the Australian government in 2011 through an Australian Agency for International Development (AusAID) initiative with the principal goal of assisting mineral-rich developing countries in lifting the quality of life of their local populations through a more sustainable use of their mineral resources. ${ }^{25}$ It is a major component of Australia's Mining for Development Initiative under which Australia intends to "share its significant expertise and experience in mining to assist resource-rich developing countries maximise the benefits and opportunities of mining." ${ }^{26}$ AusAID committed the sum of AUD31million to the Centre, to be paid in four tranches: AUD7million in October 2011, AUD7million in July 2012, AUD8million in July 2013 and AUD 9 million in July 2014. ${ }^{27}$ The UWA and the University of Queensland collaboratively operate the Centre, with its headquarters at the University of Western Australia (UWA). Owing to a non-renewal of funding by AusAID

23 Donald E Abelson, "Do Think Tanks Matter? Opportunities, Constraints and Incentives for Think Tanks in Canada and the United States" (2000) 14(2) Global Society, pp. 217-218.

24 ibid.

25 IM4DC, International Mining for Development Centre: Australia Aid Activity Proposal Submitted by the University of Western Australia and the University of Queensland, 22 September 2011, <http://dfat.gov.au/about-us/publications/ Documents/mining-im4dc-ausaid-activity-proposal.pdf $>$ accessed 19 December 2015.

26 IM4DC, IM4DC Highlights 2013 p 3, <http://im4dc.org/wp-content/uploads/ 2013/05/IM4DC-Highlights-2013.pdf> accessed 19 December 2015.

27 Australia Agency for International Development, Grant Agreement Deed between Commonwealth of Australia, represented by the Agency for International Development (AusAID) and University of Western Australia, for International Mining for Development Centre, 20 October 2011, <http:// aid.dfat. gov.au/aidissues/mining/Documents/mining-im4dc-signed-grantagreement.pdf $>$ accessed 19 December 2015. 
after the last tranche of funds was paid in July 2014, IM4DC suspended (or completed) its activities in mid-2015. However, in order to continue the work of IM4DC pending when further funding becomes available, the two partner institutions, in partnership with other agencies, institutions and donors, formed the Minerals and Energy for Development Alliance. Their work builds on the momentum created by IM4DC. ${ }^{28}$

IM4DC is aligned closely with AusAID's development assistance programmes and is committed to engaging closely with AusAID to ensure optimal realisation of the goals of those programmes. Specifically, it includes AusAID's Sustainable Mining Initiative aimed at expanding its programmes in the minerals and petroleum sector in developing countries, particularly Africa, and at contributing to the improvement of Australia's reputation in the mining sector. ${ }^{29}$ According to IM4DC's AusAID Activity Proposal, it represents a paradigm shift in Australia's Official Development Assistance (ODA) in that, rather than being oriented towards achieving Australia's business growth goals, it focuses on "delivering outcomes that will benefit Australia through the benefits that accrue to the receiving countries." 30

IM4DC's work is organised around three themes, namely, governance and regulation, community and environmental sustainability, and operational effectiveness. ${ }^{31}$ Under the first theme, it is believed that in order for mineral development to bring prosperity to global-south countries, there is a need to establish a sustainable governance mechanism that effectively accounts for resource revenues while promoting safe, healthy, gender-sensitive, ethnically inclusive, environmentally friendly and socially responsible development. ${ }^{32}$ The second theme (community and environmental sustainability) recognises the potential of mineral resources to contribute positively to local resource bases while simultaneously impacting negatively on specific areas. This theme, therefore, focuses on addressing the negative impacts of mineral development on local communities and the environment. The third theme (operational effectiveness) recognises that much of the expertise and technology needed to effectively develop the minerals industry is not available in developing countries. ${ }^{33}$ It, therefore, focuses on how to deploy Australian expertise and

28 Minerals and Energy for Development Alliance, <http://mefda.org.au/> accessed 19 March 2016.

29 ibid.

30 ibid 9.

31 ibid.

32 ibid.

33 ibid. 
technology to assist developing countries in growing their minerals sector.

IM4DC's strategy for the implementation of the above objectives includes the organisation of education and training programmes on core issues relevant to mining development, tailored to meet the specific needs of developing countries (such as study tours for mining stakeholders in specific countries). Short mining courses are organised both in Australia and in the developing countries. The strategy also includes the organisation of a Distinguished Fellowship Programme in Australia for influential stakeholders in the mining industry; an action research programme to strengthen the capacity of developing countries in specific areas; an annual international mining for development conference held in Australia; and the provision of technical advice to the Australian government. ${ }^{34}$

As stated in its 2013 report, IM4DC has hosted two international conferences and 11 fellowships in Australia, and organised 30 short courses, workshops and study tours, with 900 participants from 36 developing countries in attendance. ${ }^{35}$ Sometimes, the study tours have involved high- level government officials from developing countries. In 2012, for example, 20 Ugandan parliamentarians and government officials, led by Uganda's Energy Minister, were in Australia to study the legislative and governance frameworks for Australia's extractive industries. ${ }^{36}$ Some of the issues dealt with in the short courses include: extractive industries negotiation skills, geographic information systems, relations with indigenous peoples, environmental and social aspects of bauxite mining and mine closure, and management of large volume wastes. ${ }^{37}$ The courses and study tours are intended to be a learning experience for the participants, an experience that they are expected to use in their home countries. They are thus essentially capacity building programmes.

IM4DC has made conscious effort to raise its profile in Africa. This is demonstrated by the fact that among the 42 countries where it carries on its activities, 26 are African..$^{38}$ It has established a number of collaborations with African universities, such as the University of Zambia, the Copperbelt University (also in Zambia) and the University of Mines and Technology,

34 ibid.

35 IM4DC (Highlights, 2013) (n 26).

36 ibid.

37 ibid.

38 The African countries include: Algeria, Burkina Faso, Cote d'Ivoire, Democratic Republic of Congo, Ethiopia, Gabon, Gambia, Ghana, Guinea, Kenya, Lesotho, Liberia, Madagascar, Malawi, Mali, Morocco, Mozambique, Niger, Nigeria, Republic of Congo, Sierra Leon, South Africa, Tanzania, Uganda, Zambia and Zimbabwe. 
Ghana. ${ }^{39}$ It is currently concluding partnership agreements with the AMDC and the African Institute for Economic Development and Planning for the purpose of implementing the AMV. ${ }^{40}$ The collaboration will, among other things, facilitate the further development of short courses, research and staff development for Africans.

\subsection{The CIRDI}

Shortly before the merger between CIDA and the Department of Foreign Affairs, Trade and Development Canada (DFATD) in 2013, CIDA initiated the creation of CIRDI. It focused on "help[ing] resource-rich developing countries [to] make better use of and derive more benefit from their extractive sectors in order to reduce poverty and stimulate sustainable economic growth" (DFATD, 2014a). ${ }^{41}$ The institute, headquartered at the University of British Columbia and managed collaboratively with Simon Fraser University and École Polytechnique de Montreal, works in three areas: natural resource governance, environmental protection, and economic development and diversification. Its take-off funding was a US $\$ 24.6$ million contributed by CIDA in May 2013 over a five-year period (2013-2018). ${ }^{42}$ It works in partnership with the Canadian government, civil society and industry, and undertakes projects funded by DFATD, its own partners and other development organisations. ${ }^{43}$ It is aligned with Canada's corporate social responsibility strategy titled Building the Canadian Advantage: A CSR Strategy for the Canadian Extractive Sector Abroad, unveiled in March 2009 and revised in November 2014. The CSR "aims to improve the competitive advantage of Canadian extractive sector companies by enhancing their ability to manage social and environmental

39 IM4DC, "African Minerals Development Centre and IM4DC Collaborate in Africa", 10 March 2014, <http://im4dc.org/african-minerals-development-centre-andim4dc-collaborate-in-africa/> accessed 18 February 2016.

40 ibid.

41 Department of Foreign Affairs, Trade and Development (DFATD), Canada, Project Profile: Creating the Canadian International Institute for Extractive Industries and Development (last modified 20 December 2014), <www.acdi-cida.gc.ca/ cidaweb\%5Ccpo.nsf/projEn/S065811001> accessed 19 February 2016.

42 CIRDI, Funding Structure (2014) <www.ciieid.org/about/funding-structure/ $>$ accessed 19 February 2016.

43 CIRDI, "Who We Are", (2014) <www.cirdi.ca/wp-content/uploads/2014/01/ CIRDI-Brochure_web_2014Nov.pdf $>$ accessed 19 February 2016. 
risks" (DFATD, 2009). ${ }^{44}$ Observably, it also intends to contribute to the implementation of Canada's new foreign aid policy, which places great emphasis on partnerships with the private sector in developing countries, towards enhancing the development impact of the operations of Canadian companies in those countries. ${ }^{45}$

CIRDI's programmes are organised around four themes, namely, sustainable development and governance of the extractive sector, transformation of artisanal and small-scale mining, multi-stakeholder integration of extractive projects in communities, and economic diversification and local supply chains. The practical steps required to deliver these programmes are less explicit and concrete than those of IM4DC, but they are described as "adopting diverse perspectives and inclusive approaches, and working across many disciplines." ${ }^{16}$ In February 2014, at the behest of six civil society organisations, the Institute organised a participatory workshop for community members and government representatives in Portovelo, Ecuador, on business opportunities and local entrepreneurship programmes that promote local economic diversification. In July 2015, it organised a summer institute, a learning event in Vancouver, Canada, on resource governance part of a 10day pilot programme involving 31 participants from 17 developing countries. ${ }^{47}$ It is collaborating with the Ministry of Mines in Kenya to prepare a mineral audit report for the Kenyan government. ${ }^{48}$ The Institute intends to establish

44 Centre for Excellence in Mining, Building the Canadian Advantage: A CSR Strategy for the Canadian Extractive Sector Abroad, (undated), <http://web.cim.org/ UserFiles/File/Building-Canadian-Advantage-CSR-Strategy-ExtractiveSector.pdf $>$ accessed 19 February 2016.

45 DFATD, Canada promotes private-sector-led development to help the world's most vulnerable people, 11 June 2013, <www.international.gc.ca/media/dev/ news-communiques/2013/06/11a.aspx?lang=eng $>$ accessed 19 February 2016; Graeme Douglas \& Shannon Kindornay, "Development and the Private Sector: Canada's Approach", North-South Institute Research Paper, September 2013, <www.nsi-ins.ca/wp-content/uploads/2013/10/Development-and-thePrivate-Sector-Canada\%E2\%80\%99s-Approach-updated.pdf $>$ accessed 19 February 2016; Chilenye Nwapi, "Resource Extraction in the Courtroom: The Significance of Choc $v$ Hudbay Minerals Inc for Transnational Justice in Canada" (2014) 14 Asper Review of International Business and Trade Law 118-156.

46 CIRDI, "Who We Are" (n 43).

47 CIRDI, "CIRDII Summer Institute on Resource Governance: New Beginnings", (7-18 July 2015), < http://cirdi.ca/programming/cirdi-summer-institute/> accessed 19 April 2016.

48 CIRDI, "Kenya Audit Report Delivered" (January 2016) < http://cirdi.ca/kenyamineral-audit-delivered/> accessed 19 April 2016. 
an International Training Centre for Artisanal Mining that will serve as a training ground for artisanal miners to enable them evolve into successful mining entrepreneurs. ${ }^{49}$

Unlike IM4DC, however, most of CIRDI's activities are currently concentrated in Latin America, although its stated regional focus comprises Africa (35\%), Americas (35\%) and Asia (30\%). ${ }^{50}$ Among Canada's 25 development countries of focus, 10 are African countries. ${ }^{51}$ In February 2014, the Institute signed a letter of intent with AMDC to cooperate on the implementation of the AMV. Areas of interest include the development of policy and regulatory frameworks, geological information systems, mining governance and stakeholder participation, and human and institutional capacity building. ${ }^{52}$

\subsection{A Critique of IM4DC's and CIRDI's Programmes and Strategies}

To be clear, the foregoing strategies and programmes are laudable. Workshops and trainings (which are often accompanied by scholarships to make them cost-free for the participants) are certainly useful in reducing poverty and inequality in Africa. They would be most effective if they are designed to offer training first and foremost to mining industry personnel as well as personnel of government mining agencies and departments who would return to their jobs at the end of their programme to utilise the knowledge and skills acquired. CIRIDI's summer institute (earlier referred to) is commendable, as the

49 CIRDI, "Economic Diversification and Community Development of Artisanal Mining Towns" (31 March 2014), <www.cirdi.ca/economic-diversification-andcommunity-development-of-artisanal-mining-towns/> accessed 19 December 2015.

50 DFATD, "Project Profile" (n 41).

51 DFATD, "Canada Updates List of Development Countries of Focus" (27 June 2014), <www.international.gc.ca/media/dev/newscommuniques/2014/06/ 27abg.aspx?lang $=$ eng\&utm_source $=$ mailoutinteractive\&utm_medium $=$ email\& utm_campaign =BCCIC\%20August $\% 20$ Newsletter $>$ accessed 19 February 2016. The countries are: Benin Republic, Burkina Faso, Democratic Republic of Congo, Ethiopia, Ghana, Mali, Mozambique, Senegal, South Sudan and Tanzania.

52 All Africa, "Canadian Institute Signals Intent to Support the Africa Mining" (2 February 2014), <http://allafrica.com/stories/201402032006.html> accessed 19 February 2016; CIRDI, "Africa: Canadian Institute Signals Intent to Support the Africa Mining Development Centre", 2 February 2014, $<$ www.cirdi.ca/africa-canadian-institute-signals-intent-to-support-the-africamining/> accessed 19 February 2016. 
participants included extractive industry professionals from government, civil society and academia who had a role to play in shaping the mining industry in their countries. Also, IM4DC's programme on strengthening geoscientific knowledge $\mathrm{e}^{53}$ is noteworthy, as it would help to improve geological information available to host governments. Such information can contribute to increasing the capacity of host governments in negotiating with mining companies. ${ }^{54}$

However, these workshops and trainings should also be extended to persons who are not already mining industry personnel. For these latter participants, incentives, such as an absorption plan into the local workforce, to be undertaken by the recipient country, should accompany the capacity building, so that the country can benefit from them. This can help to address the problem associated with, "the migration of skilled workers abroad". For instance, Kaplan decried migration as a major factor aggravating the skills shortage in South Africa, pointing out specifically how Australia has been successful in recruiting South African skilled workers. ${ }^{55}$ This brain drain is a marked obstacle to the realisation of the AMV.

In addition, it does not appear that the activities of these think-tanks are well integrated into the private sector and local communities in developing countries. Their major partners have been government institutions: ministries, departments and agencies as well as public universities. Partnerships with local communities and local artisanal and small-scale miners seem minimal. In a 2013 study of Canadian and Australian mining sector-related development initiatives abroad, Marcano found that Canada Building the Canadian Advantage initiative placed more emphasis on working more closely with Canadian mining companies and non-governmental organisations abroad. ${ }^{56}$ Dissimilarly, Australia's Mining for Development initiative had placed more

53 IM4DC, "Highlights 2013" (n 26).

54 Economic Commission for Africa (ECA) \& African Union (AU), Minerals and Africa's Development: The International Study Group Report on Africa's Mineral Regimes, 2011, <http://www.uneca.org/sites/default/files/publications/ mineral_africa_development_report_eng.pdf $>$ accessed 19 February 2016.

55 David Kaplan, "South African Mining Equipment and Specialist Services: Technological Capacity, Export Performance and Policy" (2012) 37 Resources Policy, p. 430.

56 Mercedes Marcano, Mining and Development: A descriptive Study of the Canadian and Australian Development Initiatives in the Countries where their mining companies Operate (Graduate School of International Affairs, University of Ottawa, Major Research Paper, August 2013) 32, <www.ruor.uottawa.ca/ bitstream/10393/26077/1/MARCANO\%2c\%20Mercedes\%2020135.pdf> accessed 19 February 2016. 
emphasis on working directly with other governments to support the development of the mining sector in those countries. She described the Canadian initiative as "an initiative, which gives a strong focus to protecting Canadian private investments abroad." ${ }^{57}$ Arguably, it is this sort of lack of [adequate] engagement with the local communities and the private sector in developing countries that has prompted scholars such as Stone to dispel as "myth," the idea that think-tanks act in the public interest, "being a conduit for public participation and force for democratic consolidation." 58

Nevertheless, building the capacity of government institutions is critical to the realisation of the AMV. This is because, like other countries transitioning from a state- to a market-based economy, African countries are forced to introduce new institutions required for its smooth running and must learn to design and implement a new set of socio-economic instruments. ${ }^{59}$ Policy makers in such countries are generally ill prepared for this challenge, "since their education, training and experience" are inadequate for it. ${ }^{60}$ Think-tanks can play a transformative role by assisting African policy makers to face this challenge. ${ }^{61}$ According to the UNDP, think-tanks "are the bridge between knowledge and power in modern democracies". ${ }^{62}$ They "represent a vital component of successes of policies directed towards harmonisation of existing practices with contemporary paradigms of good governance and economic management." ${ }^{63}$

Furthermore, governance, understood as "the systems of authoritative norms, rules, institutions, and practices by means of which any collectivity, from the local to the global, manages its common affairs", ${ }^{64}$ is one of the

57 ibid 32 .

58 Diane Stone, "Recycling Bins, Garbage Cans or Think Tanks? Three Myths Regarding Policy Analysis Institutes" (2007) 85(2) Public Administration, pp. 260-261.

59 Toru Hashimoto, Stefan Hell \& Sang-Woo Nam, "Introduction" in Toru Hashimoto, Stefan Hell \& Sang-Woo Nam, eds, Public Policy Research and Training in Vietnam (Asian Development Bank Institute, 2005) p. 20.

60 ibid.

61 ibid.

62 United Nations Development Programme, Thinking the Unthinkable: From Thought to Policy - The Role of Think Tanks in Shaping Government Strategy: Experiences from Central and Eastern Europe (UNDP Regional Bureau for Europe and the Commonwealth of Independent States) 6.

63 Diane L. Stone, "Think Tanks and Policy Advice in Countries in Transition" In Hashimoto, Hell and Nam, eds. (n 60) 38.

64 John Gerard Ruggie, "Global Governance and "New Governance Theory: Lessons from Business and Human Rights" (2014) 20 Global Governance 5. 
major challenges to sustainable mineral resource development in Africa. ${ }^{65}$ The most important institutions are those with responsibility for regulating the environmental impact of mineral development, those with responsibility for designing mineral fiscal regimes and for collecting and auditing mineral revenue, those in charge of geological survey, and those that offer training in science and technology. ${ }^{66}$ Observably, for these institutions to be effectively strengthened, appropriate linkages between them and the private sector need to be developed to foster interactions between them that would facilitate knowledge sharing. Moreover, as recognised by AMSI, capacity building, or "mineral skills", should be viewed holistically to include not only engineering and geological skills, but also capacity in such areas as "strategic planning, law, finance, fiscal policy, environment, community affairs and human rights". ${ }^{67}$ Moreover, to effectively build the capacity of government institutions, the private sector and local communities in the mining sector in Africa must be treated as a source of vital knowledge. This entails think-tanks' active engagement with these two entities.

Genuine development aid must be geared towards assisting African countries to take ownership of the development of their resources, to mark an end to or reduce Africa's dependence on foreign investors. Certainly, due to the capital intensive nature of mineral development and the level of technical knowhow required, increasing Africa's ownership of its mineral sector is a huge challenge. In the short term, foreign companies operating in Africa would necessarily have to import much of their expertise and technology. In the long term, however, the goal must be to develop in-country expertise and technology through incremental knowledge transfer, as this would potentially broaden the possibilities for Africa to take ownership of its resources.

This would entail bringing African mining companies into the centre of capacity building programmes to enable them grow gradually in skills acquisition and improve their capital base. This does not seem to be on the front burner of IM4DC and CIRDI programmes. Instead, the primary target of the programmes comprises mostly government institutions. As IM4DC noted in its 2014 mid-term review, industry has expressed concern over their lack of

65 ECA \& AU (n 53).

66 ibid.

67 Natasha Odendaal, "New initiative to boost 'mineral skills' in Africa" Mining Weekly (23 October 2012), <www.miningweekly.com/article/new-initiativelaunched-to-boost-mineral-skills-in-africa-2012-10-23> accessed 19 February 2016 (quoting Richard Duffy, AngloGold Ashanti executive vice president for Africa). 
integration into IM4DCs activities. ${ }^{68}$ IM4DC concedes that this is "a serious weak point" in its activities; but it seeks to defend this weakness by attributing the minimal involvement of industry to "instructions from AusAID from the early days" of IM4DCs establishment. ${ }^{69}$ Such an instruction cannot be understood, given that a major part of IM4DCs work is to deliver aid to developing countries through establishing partnerships with the private sector in those countries. If the industry, the major player in the private sector in developing countries, is kept, as a matter of the Australian government policy, at the fringes of IM4DCs activities, then the genuineness of the development aid policy is suspect. This likely explains why some critics have described the shift from government-to-government development aid delivery to the use of the private sector, such as think-tanks, as a calculated strategy by developed countries to avoid directly regulating the activities of their extractive companies abroad, with Parfitt, Bryant \& Barrett $(2011: 69)^{70}$ calling it "a flawed development model".

To be sure, establishing institutional links is important, for it gives thinktanks the political protection they sorely needed to carry on their activities effectively. But a desperate focus on establishing links with government institutions might undermine a think-tanks' ability to identify the exact type of capacity that needs strengthening. Indeed, more often than not, the government institutions in developing countries are too far removed from the local communities and the industry to know what their real needs are. Programmes that are more community-oriented, which engage adequately with local industry and that strengthen the capacity of local mining companies to acquire the expertise and other wherewithal to undertake large-scale mining projects ought to be given priority and vigorously promoted. It is such programmes that have the capacity to give foreign mining companies the profoundly needed social license to operate.

Moreover, capacity building has largely been treated, as something needed only by developing countries. But the reality is that the capacity of foreign

68 IM4DC, "Mid-Term Review" (n 5).

69 ibid 9.

70 Claire Parfitt, Gareth Bryant \& Liz Barrett, “Australia's Mining for Development Initiative: Blurring the Boundaries Between Private Profit and Public Development" in Brian Tomlinson (ed), Aid and the Private Sector: Catalysing Poverty Reduction and Development? Reality of Aid 2012 Report (IBON International, 2012) 69, <www.realityofaid.org/wp-content/uploads/2013/ 02/ROA_Report_2012-Aid_and_the_Private_Sector1-final.pdf $>$ accessed 19 January 2016. 
mining companies operating in Africa to understand the complexity of the communities in which they operate and to understand how to manage the multiplicity of interests involved to avoid social tensions and violent confrontations that all too often lead to internecine conflicts also needs strengthening. The heterogeneous nature of African local communities and the multiplicity of interests this produces, as illustrated by several studies, ${ }^{71}$ render company-community relations in the mineral sector especially difficult. ${ }^{72}$ Government-initiated international development think-tanks ought, therefore, to consider programmes and strategies to assist their companies operating in Africa to strengthen their capacity - particularly their social capacity - to operate in those countries.

Another concern relates to the impact of government funding of these think-tanks on their effectiveness. To be clear, while the source of think-tank funding has been of concern to many observers, its influence on their activities is for the most part a matter of presumption. Many commentators believe that governments and their agencies have vested interests that may impede their fund recipients independence and may directly influence the policy recommendations that result. ${ }^{73}$ Two US think-tanks were strongly censured in 2013 for accepting money from Taiwan ${ }^{74}$ and Qatar. ${ }^{75}$ In India, a think-tank

71 See for instance, Alberto Alesina et al, "Fractionalisation", Harvard Institute of Economic Research Discussion Paper No 1959, 2002, <http:// dash.harvard.edu/bitstream/handle/1/4553003/alesinassrn_fractionalisation. pdf? sequence $=2>$ accessed 19 January 2016 .

72 Ernst and Young, "Business Risks Facing Mining and Metals 2014-2015" (Ernst and Young, 2013) <www.ey.com/Publication/vwLUAssets/EY-Business-risksfacingminingandmetals2014\%E2\%80\%932015/\$FILE/EY-Business-risksfacing-mining-andmetals2014\%E2\%80\%932015.pdf > accessed 19 January 2016.

73 G. Bentley, "The State Funding Swindle: How Left Wing Think-tanks are Pulling Taxpayer-funded Wool over Our Eyes" (September 2012) <www.the commentator.com/article/1679/the_state_funding_swindle _how_left_wing think_tanks_are_pulling_taxpayer_funded_wool_over_our_eyes $>$ accessed 19 January 2016.

74 E Clifton, "The Secret Foreign Donor Behind the American Enterprise Institute", The Nation (25 June 2013), <www.thenation.com/article/174980/secretforeign-donor-behind-american-enterprise-institute\# $>$ accessed 19 January 2016.

75 D. Byers, "Goldberg slams Brookings, via Qatar", Politico, 2 May 2013, <www.politico.com/blogs/media/2013/05/goldberg-slams-brookings-via-qatar163106.html> accessed 19 January 2016. 
must obtain government approval before accepting foreign funding. ${ }^{76}$

Although these cases relate to think tanks that accepted funding from foreign governments, they demonstrate concern that funding source matters, even within government circles. Stone however argues " $[t]$ he notion that a think tank requires independence from the state in order to be 'free-thinking' is an Anglo-American norm that does not translate well into other political cultures." 77 But she equally notes that think- tanks "sponsored and funded by international organisations and donor groups tend to be well institutionalised, mainstream institutes whose research agendas concord in considerable degree with the policy interests of their funding source." ${ }^{\text {. }}$

Indeed, funding source matters. AusAID's instruction to IM4DC to engage only minimally with industry and IM4DCs apparent compliance with that bidding is a clear demonstration that funding source matters. Although IM4DC has pledged to give industry greater opportunity to participate in its programmes and planning ${ }^{79}$ it remains to be seen whether this will go down well with AusAID and to what extent IM4DC would allow industry such opportunities. With regard to CIRDI, critics have argued that CIRDIs funding from the Canadian government "compromises its independence" and may lead it to place Canadian economic interests over the interests of the local populations in countries of operation. ${ }^{80}$ Former University of British Columbia president, Stephen Toope, however, is reported to have rebutted this argument, describing CIRDI as, "an independent academic centre [that] is not an instrument of the government of Canada". ${ }^{81}$ At the end of 2018 when CIDAs funding will terminate, CIRDI will be expected to become self-sustaining, relying on "expanded service offerings and ... the support of multiple stakeholders" (CIRDI, 2014d). ${ }^{82}$ These multiple stakeholders, it can be presumed, would include external funding agencies, Canadian mining companies and mining industry associations. Balancing the interests of industry, government, the

76 C Jenkins, "Philanthropic funds take different route", Live Mint (20 August 2013) < http://origin-www.livemint.com/Companies/RFVtI9uFQFU91w8i WkyokM/Philanthropic-funds-take-different-route.html> accessed 19 January 2016.

77 Stone, "Think Tanks and Policy Advice" (n 64) 42.

78 Stone, "Recycling Bins" (n 59) 269.

79 IM4DC, "Mid-Term Review" (n 5).

80 A. Rosenfeld, "International mining institute opens at UBC, critics question its independence", The Ubyssey, (1 February 2014) < http://ubyssey.ca/news/ubcmining-institute-324/> accessed 19 January 2016.

81 ibid.

82 CIRDI, "Funding Structure" (n 42). 
academia and the local populations in developing countries (the avowed targets of the institutes programs) must be difficult. Cooley and Ron have consequently observed that in the effort to "reconcile material pressures with normative motivations", think- tanks "often produce outcomes dramatically at odds with liberal expectations." 83

Still, "[a] little dependence", as one scholar has pointed out, may be a positive thing, as it could help to assure the availability of resources for more relevant and worthy programmes. ${ }^{84}$ It becomes disconcerting when the dependence rises to a level that the think-tanks programmes are predestined to meet the often parochial expectations of its funders. ${ }^{85}$ This concern is accentuated by the fact that CIRDI and IM4DC are integrated into the foreign aid policy of their respective countries as an important tool of economic diplomacy.

\subsection{Harnessing the Opportunities of IM4DC and CIRDI: Local Content Requirements}

Despite the above criticisms, the importance of IM4DC and CIRDI in the realisation of the AMV cannot be denied. The AMV recognises lack of professional and technical capacity as a major factor hindering the ability of most African countries to turn their mineral potential into reality. This lack of capacity is probably most apparent and distressing in Rwanda, a country whose professional class was virtually annihilated during the 1994 genocide. A 2012 skills survey showed that the Rwandan mining sector alone had a total skills gap of 2,721 labour units, resulting in almost complete reliance on foreign mining professionals and technicians, but with the low salary package offered in Rwanda, attracting highly skilled experts has been difficult. ${ }^{86}$

The programmes developed by IM4DC and CIRDI can contribute to the much-needed professional and technical capacity for their African partner

83 Alexander Cooley \& James Ron, "The NGO Scramble: Organisational Insecurity and the Political Economy of Transnational Action" (2002) 27(1) International Security 6.

84 N. Krishna, "Think Tank Effectiveness - An Outsider View" (1 December 2014) $<$ http://onthinktanks.org/2014/12/01/think-tank-effectiveness-an-outsiderview/> accessed 20 January 2016.

85 ibid.

86 Rwanda Development Board, Mining Sector Report: Rwanda Skills Survey 2012, (2012) <www.lmis.gov.rw/scripts/publication/reports/Mining.pdf > accessed 20 January 2016. 
countries. This may not happen unless African governments key prudently into those programmes, through the development of policy and legal frameworks, that integrate local capacity building into mining development and expand opportunities for value addition in the mining sector. Local skills have been developed through the establishment of educational institutions and skills acquisition centres as well as the sort of trainings that IM4DC and CIRDI have engaged in. An approach increasingly being embraced by many countries, global-north or south, involves local content requirements (LCRs).

LCRs are designed to enable a country maximise the gains of Foreign Direct Investments (FDI) by mandating the use of local firms in goods and services procurement, employment of local populations and the use of local raw materials by investors. ${ }^{87}$ It is conceptualised as the requirement that "a given percentage of domestic value added or domestic components be embodied in a specified final product". ${ }^{88}$ LCRs represent a form of intervention known as "productive development policies" whose goal is to "strengthen the productive structure of a particular national economy." ${ }^{\prime 99}$ They are undertaken to: (1) increase the participation of the domestic industry in specific sectors of national economic activity; (2) improve national technological development; (3) create job opportunities for nationals to improve their livelihood; (4) support economic diversification and thereby reduce overdependence on one sector by strengthening the value-creating capacity of a particular sector; and (5) enhance the capacity of domestic companies to compete regionally and internationally. ${ }^{90}$ The requirements are either

87 G. Ugo Nwokeji, "The Nigerian National Petroleum Corporation and the Development of the Nigerian Oil and Gas Industry: History, Strategies and Current Directions" (Paper presented at the James A Baker III Institute for Public Policy, Rice University, March 2007) < http://bakerinstitute.org/media/ files/page/9b067dc6/noc_nnpc_ugo.pdf $>$ accessed 29 January 2016.

88 G. M. Grossman, "The Theory of Domestic Content Protection and Content Preference" (1981) 6(4) Quarterly Journal of Economics 583.

89 A. Melo \& A. Rodriguez-Clare, "Productive Development Policies and Supporting Institutions in Latin America and the Caribbean", (Inter-American Development Bank Research Department Competitive Studies Series Working Paper C-106, February 2006) 5 <www.iadb.org/res/publications/pubfiles/pubc-106.pdf> accessed 29 January 2016.

90 Silvana Tordo et al, Local Content Policies in the Oil and Gas Sector, World Bank Study, (Washington, DC, 2013) <www-wds.worldbank.org/external/default/ WDSContentServer/WDSP/IB/2013/07/12/000445729_20130712141852/ Rendered/PDF/789940REVISED000Box377371B00PUBLIC0.pdf $>$ accessed 29 January 2016; International Petroleum Industry Environmental Conservation Association, "Local Content Strategy: A Guidance Document for the Oil and Gas Industry" (2011) <www.ipieca.org/publication/local-content-strategyguidance-document-oil-and-gas-industry> accessed 29 January 2016. 
implanted in contractual agreements between governments and companies or enacted legislatively. Sometimes they are established in bidding requirements as part of the criteria for winning contracts or, more indirectly, established in regulations and tax regimes that discriminate in favour of local industries. ${ }^{91}$

Many African countries have adopted LCRs in one form or another, but few apply it in the mining sector. In Nigeria, for instance, it has been adopted only in relation to the oil and gas industry, under the Nigerian Oil and Gas Industry Content Development Act, 2010. The Nigerian Minerals and Mining Act, 2007 merely requires the responsible Minister to "introduce investment friendly local content measures for mining projects" and to "facilitate the development of indigenous technical and professional manpower required in the mineral resources sector" (section 4(q) and (r)). These provisions are largely discretionary and are not to be compared, in substance, form or scope, with the provisions of the oil and gas content law. The latter specifically and explicitly mandates oil and gas companies operating in Nigeria to meet specified local content levels in matters of employment and procurement of goods and services.

In 2015, the Tanzanian government enacted a new petroleum law containing provisions for LCRs, ${ }^{92}$ suggesting that the application of LCRs would be limited to the oil and gas industry. LCR in the mining sector would remain limited to the lean and, to an extent, even discretionary provisions contained in Tanzania's Mining Act, 2010.93

In Zimbabwe, LCRs are evident in the Mines and Minerals Act. This requires mineral rights applicants to show information on the extent to which

91 WTI Advisors, "Local Content Requirements and the Green Economy" (Paper presented at the Ad Hoc Expert Group Meeting on Domestic Requirements and Support Measures in Green Sectors: Economic and Environmental Effectiveness and Implications for Trade, 13-14 June 2013, Salle XXI, Palais des Nations Geneva) <http://unctad.org/meetings/en/Contribution/DITC_TED_13062013_ Study_WTI.pdf $>$ accessed 29 January 2016; See, also, Chilenye Nwapi, "Defining the 'Local' in Local Content Requirements in the Oil and Gas and Mining Sectors in Developing Countries" (2015) 8(1) Law \& Development Rev 191.

92 The Petroleum Act, 2015, Gazette of the United Republic of Tanzania No 22 Vol. 96 dated 29th May, 2015, <www.policyforum-tz.org/sites/default/files/ BILLpetroleumACT2015UpdatedVersion15615.pdf > accessed 29 March 2016.

93 For instance, section 10(4)(e) of the Act authorises the Minister of Mines to enter into a development agreement with a holder of or applicant for a mineral right, which may contain binding provisions that "guarantee procurement of goods and services available in the United Republic". See, also, sections 44(v) and 49 (h) of the Act. 
local goods and services would be utilised in the development and operation of their mine. It further requests details of the labour needs of the proposed mine, including the number of foreign staff to be hired and any proposals for training Zimbabweans. ${ }^{94}$

In South Africa, LCRs express themselves in the Broad-Based SocioEconomic Empowerment Charter for the South African Mining and Minerals Industry, otherwise known as the South African Mining Charter (introduced in 2002 and amended in 2010) ${ }^{95}$ and in the Mineral and Petroleum Resources Development Act, 2002. Although these were cast in the context of historical discriminatory social and labour practices in South Africa, they serve as LCR implementation instruments.

In Ghana, the Minerals and Mining Act, 2006 requires mineral rights holders to give preference to made-in-Ghana products, service agencies and companies and partnerships in the procurement of goods and services. In matters of employment it requires mining companies to have a minimum proportion of Ghanaian staff in all categories of employment (subject to some exemptions). ${ }^{96}$ In Zambia, LCRs are found in the local procurement requirements contained in Zambia's Mines and Minerals Development Act, $2008 .{ }^{97}$ Guinea, ${ }^{98}$ Senegal ${ }^{99}$ and Sierra Leone ${ }^{100}$ also have similar provisions in their mining codes.

As the World Bank has noted, while many West African countries have adopted LCRs, the provisions of their LCRs are "insufficiently developed, disseminated, monitored, and enforced." ${ }^{101}$ Although the Bank was speaking

94 Mines and Minerals Act 2008, Title 21, s 159(3)(xii) and (xiii), $<$ www.osall.org.za/docs/2011/03/Zimbabwe_Mines_and_Minerals_Act_ Chap_21_05.pdf $>$ accessed 29 March 2016.

95 South African Department of Mineral Resources Broad-Based Socio-Economic Empowerment Charter for the South African Mining and Minerals Industry (amended), Department of Mineral Resources, 2010, <www.gov.za/sites/ www.gov.za/files/33573_838.pdf> accessed 29 January 2016.

96 Minerals and Mining Act, 2006, Act 703, s 50, <www.sdsg.org/wp-content/ uploads/2011/06/Ghana-Minerals-Act-2006.pdf > accessed 29 March 2016.

97 Act No 7 of 2008, s 25(g)-(h), <www.zambialii.org/files/zm/legislation/act/ 2008/7/mamda2008295.pdf $>$ accessed 29 March 2016.

98 Mining Code, 2013, Law L/2013/053/CNT of 8 April 2013.

99 Mining Code Law n2003-36 of November 24, 2003, <www.gouv.sn/IMG/ pdf/CODEMINIER_03_36.pdf> accessed 29 March 2016.

100 Mines and Minerals Act, 2009, Supplement to the Sierra Leone Gazette Vol. CXLI, No. 3, ss 96(2)(1) and (j), 106(2)(i) and (j), <www.sierra-leone.org/ Laws/2009-12.pdf > accessed 29 March 2016.

101 World Bank, Increasing Local Procurement by the Mining Industry in West Africa, Report No. 66585-AFR, January 2012, p. 46, <http://siteresources. worldbank.org/INTENERGY2/Resources/8411-West_Africa.pdf $>$. 
of West Africa, the situation is not likely better in other African countries and might even be worse in some. In the case of Rwanda, for instance, one expected that its 2014 mining law ${ }^{102}$ would chart an effective legal course for the rebuilding of Rwanda's capacity and set the framework for effective value addition in the mining sector. Instead, the legal provisions regarding value addition to Rwanda's economy are rather timidly worded. Article 50 of the law provides that "a mineral licence may include provisions requiring the holder" to consider the feasibility of processing and refining the mineral products in Rwanda, the goal being to add value to Rwandan economy. The use of the liberal word "may" implies that the responsible Minister is not under obligation to require mineral licence holders to give first consideration to the feasibility of processing and refining their products in Rwanda before considering elsewhere. A bold and more stringent provision permitting processing and refining outside Rwanda only where these are not feasible in Rwanda is what is needed. The government would then have to support the gradual realisation of the goal of such a requirement by providing incentives to companies to establish processing and refining plants in Rwanda and prescribing a time limit for them to do so.

In Ghana, however, steps are being taken, in consultation with stakeholders in the mining sector, to create regulation to give effect to the LCR provisions of the Ghanaian mining code. A key element of this effort is the requirement for mining companies to submit and report on a local procurement plan. ${ }^{103}$ With support from the International Finance Corporation, the Ghana Chamber of Mines has begun identifying opportunities for increasing supply and assessing support needs of local businesses. ${ }^{104}$

As the World Bank has further observed, "there is limited participation in mining supply chains by companies based in West Africa, despite existing capacity and the potential to create further capacity." 105 The Bank notes that few mining companies in West Africa have a clear policy on supporting local procurement. Instead, their procurement strategy is motivated primarily by issues like cost competitiveness, efficient and timely delivery of goods and services, security of supply and the need to obtain a social licence to ensure continuity of operations. While these are legitimate motivations, particularly

102 Law No 13/2014 of 20/05/2014 on Mining and Quarry Operations, <www.refworld.org/pdfid/53fb08cd4.pdf> accessed 29 March 2016.

103 World Bank (n 101).

104 ibid.

105 World Bank (n 101) viii. 
from a business perspective, they do not provide a solid foundation upon which a country can build its economic development agenda. Accordingly, the Bank posits that "[i]f countries in West Africa can meet, or even exceed, the level of local procurement seen in countries such as Chile, Canada, and Brazil, there is an opportunity for backward linkages to play a central role in sustainable economic development." ${ }^{106}$ These profit-motivated procurement strategies adopted by companies cannot provide such backward linkages.

Without a clear value addition strategy implemented through, especially, LCRs, African countries cannot harness the opportunities provided by the activities of international development think-tanks, such as IM4DC and CIRDI. Training programmes organised by these think- tanks would produce trainees unable to find jobs because of the profit-motivated employment policies and preferences of foreign mining companies operating in Africa. The potential consequence is that the capacity that has been built through such programmes fails to yield the desired result. African countries must, therefore, initiate clear frameworks for measuring local content and defining thresholds for value addition and local participation; and establish mechanisms for monitoring compliance. AMSI can serve as a regional vehicle for coordinating such frameworks and providing policy guidance to African countries.

As earlier indicated, AMSI adopts a holistic approach to capacity building that focuses on such skills as mining leadership, strategy setting, administrative and regulatory processes, planning and negotiation, and stakeholder and community engagement. ${ }^{107}$ One of AMSIs priorities is to provide support for educational institutions in Africa to access "curricula, innovative cross-sector learning, organisational capacity building and leadership" relating to mining. ${ }^{108}$ The significance of AMSI would lie in its ability to foster, through its programmes, the availability of mineral skills for African countries. This follows from one of the constraints to the success of LCRs in most African countries, which is the absence of adequate human capital to fill the available jobs and enable companies to fulfil their local content obligations. ${ }^{109}$ In

106 ibid.

107 ECA. "Africa Mineral Skills Initiative - Concept Note: Building Human Capacity and Strengthening Institutions in the Extractive Industries in Africa" (Pre-ADV VIII Event, 22 October 2012) < www1.uneca.org/Portals/adfviii/Documents/ Pre-ADF/PreADFVIIIConceptNote_AfricanMineralsSkills Initiative.pdf $>$ accessed 29 February 2016.

108 ibid 2.

109 Tordo et al (n 90); Ike Oguine, "Nigerian Content in the Nigerian Petroleum Industry: Legal and Policy Issues" (2011) 29 Journal of Energy and Natural Resources Law, pp. 405-430. 
addition, foreign firms that undertake training of its employees have an incentive to provide only firm-specific skills, thereby limiting the labour mobility of the trainees and any benefits to local firms that may arise from labour mobility. ${ }^{110}$ Through facilitating the availability of mineral skills, AMSI can contribute to the success of LCRs in the mining sector in Africa.

\section{CONCLUSION}

The realisation of the AMV requires concerted effort by all stakeholders. While the primary stakeholders are African countries themselves, other stakeholders include developed countries with investments in Africa's mining sector. As part of their economic diplomacy, some of these countries have established international development think tanks as a vehicle to assist developing countries where their mineral corporations operate. Australia's IM4DC and Canada's CIRDI are quintessential examples of such think-tanks. These two think-tanks have developed programmes and strategies that, despite their shortcomings, have the potential to contribute to the realisation of the AMV through the capacity building opportunities they create.

It behoves African governments to leverage the opportunities created by the activities of these think-tanks while maximising the gains of foreign direct investment in the mining sector. LCRs represent a very useful instrument that African countries can utilise. The establishment of AMSI can enhance the potential of LCRs in Africa to contribute to the realisation of the AMV.

110 Oliver Morrissey, "FDI in Sub-Saharan Africa: Few Linkages, Fewer Spill-overs" (2012) 24 European Journal of Development Research, pp. 26-31. 